\title{
STUDY REGARDING THE VERBAL - NON VERBAL COMMUNICATION BETWEEN COACHES - ATHLETES WITHIN THE PERFORMANCE SPORT DOMAIN
}

\section{ДОСЛІДЖЕННЯ ВЕРБАЛЬНО-НЕВЕРБАЛЬНОЇ КОМУНІКАЦІЇ ТРЕНЕРА ТА СПОРТСМЕНА ПІД ЧАС СПОРТИВНОЇ ПІДГОТОВКИ}

UDC 37

DOI https://doi.org/10.32843/2663$6085 / 2020 / 22-4.11$

\section{Mindrescu Veronica,}

Professor Ph. D.

Motor performance Department,

Faculty of Physical Education

and Mountain Sports

Transilvania University of Brasov

(Brasov, Romania)

Moldovan Elena,

Assoc. Ph. D.

Motor performance Department,

Faculty of Physical Education

and Mountain Sports

Transilvania University of Brasov

(Brasov, Romania)

\begin{abstract}
Communication is the basis of all processes, interactions and human relationships. It is also the basis of the efficient training of an athlete in the performance sport [1]. As Lyle explained [2], "the coach - athlete" relationship is essential in the athlete's development and the coaches who are now aware of the importance of such relationship risk to slow down or prevent the reaching of the athlete's maximum potential. To have a good communication, one must be open, honest, precise and direct. It is also important that one respects the ones involved, talks correctly, politely, in a constructive way, thus transmitting the entire message. A successful communication depends on a good inter personal relationship and the coach must communicate as efficiently as possible with the athlete, the whole team, the athlete's parents as well as with the media [3]. It is common knowledge that a positive communication and a positive attitude from the coach can lead to an athlete's best results [4]. It is also common knowledge that the reverse can happen: the aggressive communication can truly affect "the coach - athlete" relationship. The non-verbal communication represents a cumulus of massages which are not expressed through words and which can be decoded creating innuendoes. These signals can repeat, argue, replace, complete or highlight the message rendered through words. There is a difference between the verbal and the non-verbal communication: the non-verbal one presumes communication through gestures, mimics, body language and "represents the cumulus of messages which are not rendered through words and which can be decoded creating innuendoes" [5]. A correct verbal and non-verbal communication indicates a tight relationship coach and athlete and contributes to obtaining sporting performances.

Key words: verbal communication, non-verbal communication, coaches, performance athletes.
\end{abstract}

Спілкування є основою всіх процесів, взаємодій та людських стосунків. Це також основа ефективної підготовки спортсмена [1]. Як зазначив Лайл [2], взаємини «тренерспортсмен» важливі для розвитку спортсмена, а тренери, які зараз не усвідомлюють важливість таких відносин, ризикують уповільнити або запобігти розкриттю максимального потенціалу спортсмена. Для взаєморозуміння треба бути відкритим, чесним, точним і прямим. Важливо також, щоб вони поважали тих, хто бере участь у тренувальному процесі, говорили коректно, ввічливо, конструктивно, передавали точно все повідомлення. Успішне спілку вання залежить від добрих міжособистих взаємин, і тренер повинен якомога ефективніше спілкуватися зі спортсменом, усією командою, батьками спортсмена, а також із засобами маової інформації [3] Загальновідомо, що позитивне спілкування та позитивне ставлення тренера можуть сприяти найкращим результатам спортсмена [4]. Загальновідомо також, що може статися і зворотне: агресивне спілкування може істотно вплинути на стосунки «тренер - спортсмен».

Невербальна комунікація являє собою передачу інорормації, яка не виражається словами, яку можна розшифрувати за натяками. Ці сигнали можуть повторювати, аргументувати, замінювати, доповнювати або виділяти повідомлення, передане словами. Наявна різниця між вербальною та невербальною комунікацією: невербальна передбачає спілкування за допомогою жестів, міміки, мови тіла $і$ «являє собою передачу повідомлень, які не передаються через слова, і які можна розшифрувати, створюючи натяки» [5]. Правильне словесне та невербальне спілкування свідчить про тісні стосунки тренера і спортсмена, сприяє досягненню спортивних результатів.

Ключові слова: вербальне спілкування, невербальне спілкування, тренери, виступи спортсменів.
Formulation of the problem in general. The relationship between the coach and the athlete, which is rendered thought their way of communicating, influences both the athlete's evolution in his/her athletic development and the obtained results in competitions, whether we are talking about successes or failures for that matter. The aggressive attitude and aggressive gestures of a certain coach demotivates the athletes and his/her credibility decreases. The athletes often reject such behaviors and react consequently.

Highlighting previously unresolved parts of a common problem. The purpose of the research is to bring new useful arguments for improving the relationship between the coach and athlete by the verbal and non-verbal communication within the performance sport.
Formulating the goals of the article. The coach is the athletes' mentor, the person training them, the person who serves as a model. Comparing the communication perspectives between the coach and the athlete influences the non-verbal communication of the performer. the study used as a research method two questionnaires addressed to a work sample of 200 subjects of whom 150 subjects have been professional athletes (from collective sports such as handball, football and basketball and individual sports as well such as tennis, skiing and swimming) and 50 experienced coaches. These questionnaires have been applied through the help of phone calls, the internet and social media.

The used method of research has been applying in the online environment two questionnaires: 
the first formed of 30 questions addressed to performance athletes and the second formed of 30 questions addressed to coaches. The questionnaires have been divided in two different sections: the first section represents the research questions, while the second section represents the demographic questions. In applying the questionnaires in the online environment one has mentioned the fact that these questionnaires are anonymous and they do not need the names of the subjects, but better their gender. The data collected, in terms of answers, target only the statistical processes that are the subject of research. Furthermore, one has mentioned that when filling in the questionnaire they are in the agreement with the processing of personal data according to the "General Data Protection Regulation" (GDPR) which was created by the European Union with the purpose of protecting the personal data of citizens, adopted in 2018. After establishing the questions for coaches, the process is then followed by writing them in an app generating questionnaires and statistics. But since the questionnaires have not been addressed only to Romanian native speakers, one has also translated these questionnaires in English, using the Google Drive app for generating questionnaires, a well-known app also for processing the data automatically. One has also used three methods of transmitting the questionnaires, by phone, internet and social media, thus having a more rapid access to the sampled subjects.

All questions have been noted in a Word document followed by the research of other questionnaires on similar topics [6].

The results of the research. The research has had 200 subjects of whom 150 have been performance athletes and 50 coaches (figure 1), 2 questionnaires, one for athletes with 30 questions and one for coaches with 30 questions.

The distribution of questioned athletes on sporting disciplines has been the following: 112 athletes who practice collective sports and 38 athletes who practice individual sports.
Distribution of athletes according to the sport practiced

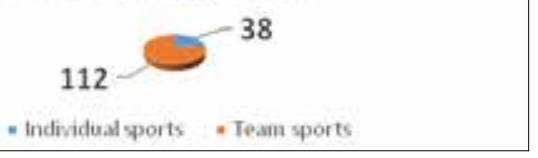

Figure 1. Distribution of respondents

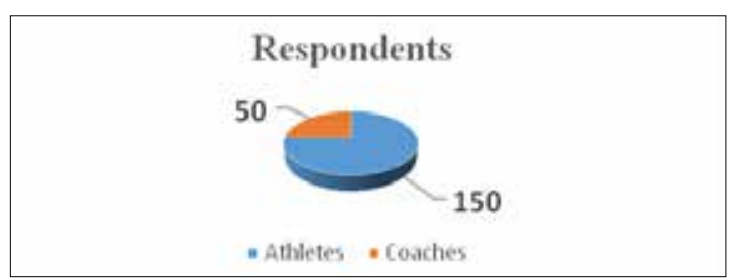

Figure 2. Distribution of athletes according to the sport practiced

In the next figure one can find the result representation of the questionnaire addressed to athletes. All the answers have been divided in positive and negative answers, even though several variants of answers have been provided. The positive answers are represented by the blue color while the negative ones by the red color (figure 3 ).

The results of the coach questionnaire can be found in figure 4.

Observing the interpretation of the total answers to the two questionnaires, we can see the aspects of the coach-athlete communication as being more negative than positive.

Hereinafter, we can see the responses to the most relevant questions that are the object of our study.

To question 1, coaches consider that only $31 \%$ of the cases have had a reverse effect, an effect of discouragement, even though their proposition was one of encouragement. The division of percentages is rendered in the following figure:

Mimics and gestures are part of the non -verbal communication. For a non-verbal message to be correctly decoded by the receiver, in this case by the coach, the latter must know his/her athlete quite well.

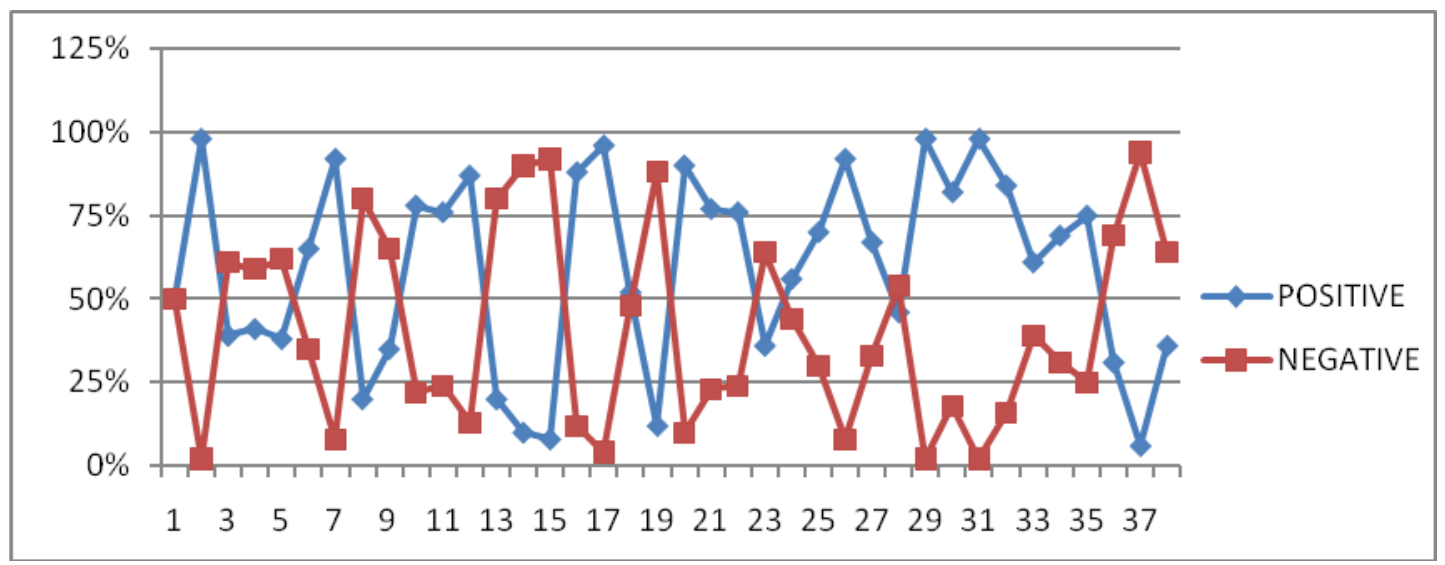

Figure 3. Results athlete questionnaire 
To question 2 addressed to coaches, "IF the athlete makes a certain gesture, a certain mimic, can you understand what he/she meant?", the result can be observed in the following figure.

To what raising one's voice is concerned, the negative percentage is quite big. The majority of athletes answer to question 3, "What effect does raising the coach's voice have on you?" with a sense of discour- agement. To question 9, similar to the previous one, $65 \%$ of athletes feel they are "less motivated to act once the coach has raised the voice", being actually quite demotivated. In comparison, coaches tend to be a bit over $50 \%$ towards the negative answer. A lot of them feel that certain athletes can be motivated only by raising their voice. This comparison, between coaches and athletes, can be seen in the following

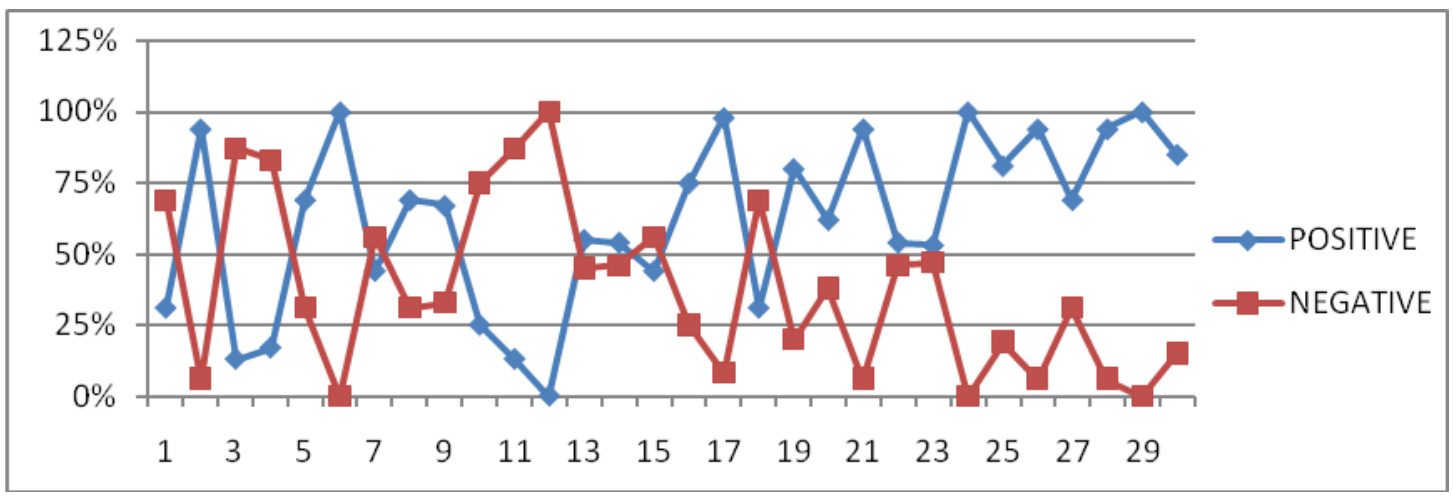

Figure 4. Results coach questionnaire

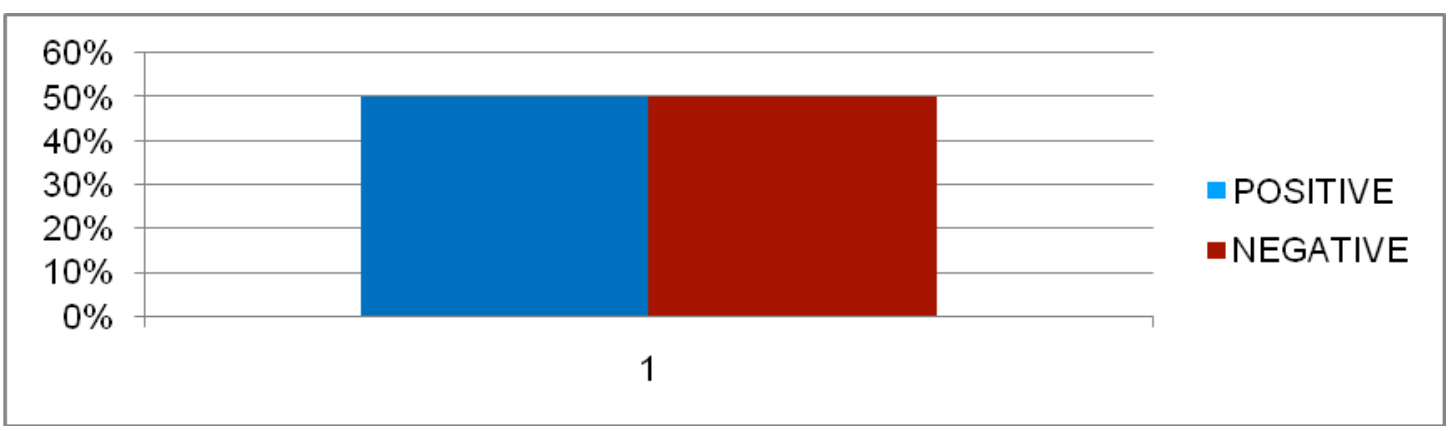

Figure 5. Question 1 athlete questionnaire

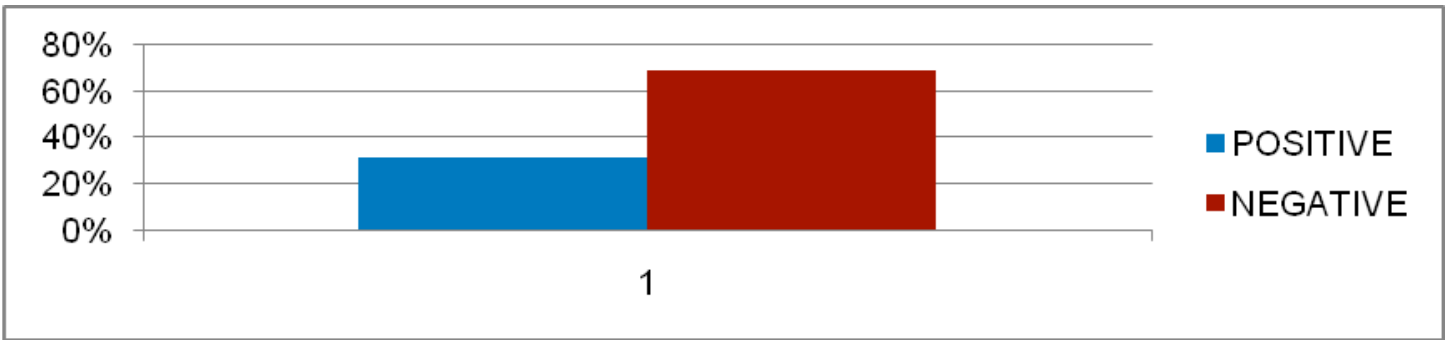

Figure 6. Question 1 coach questionnaire

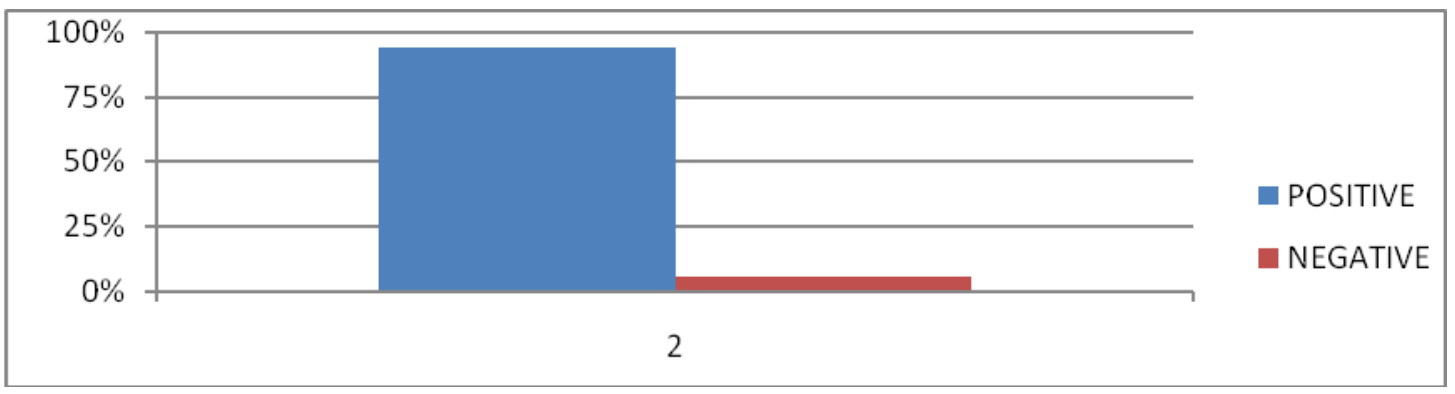

Figure 7. Question 2 


\section{ІННОВАЦІЙНА ПЕДАГОГІКА}

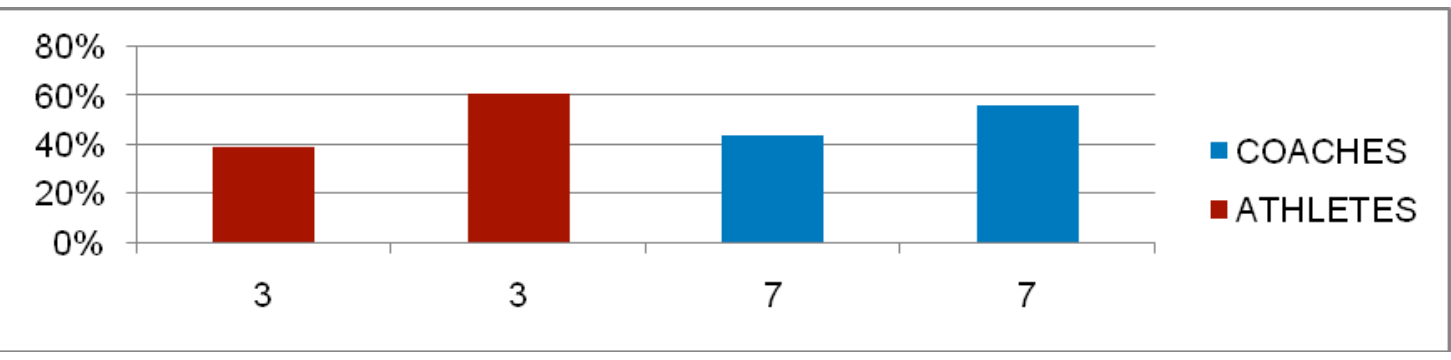

Figure 8. Question 3 (athlete questionnaire) Question 7 (coach questionnaire)

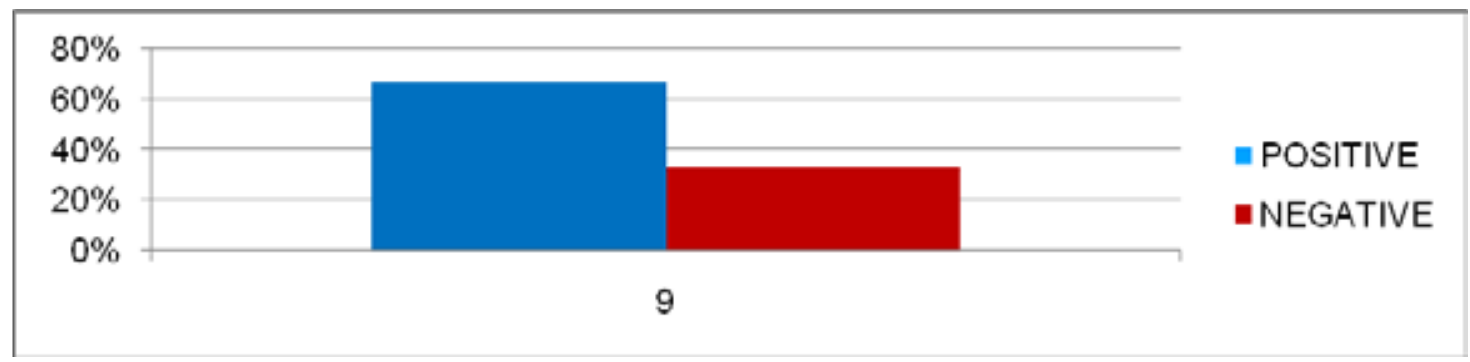

Figure 9. Question 9 coach questionnaire

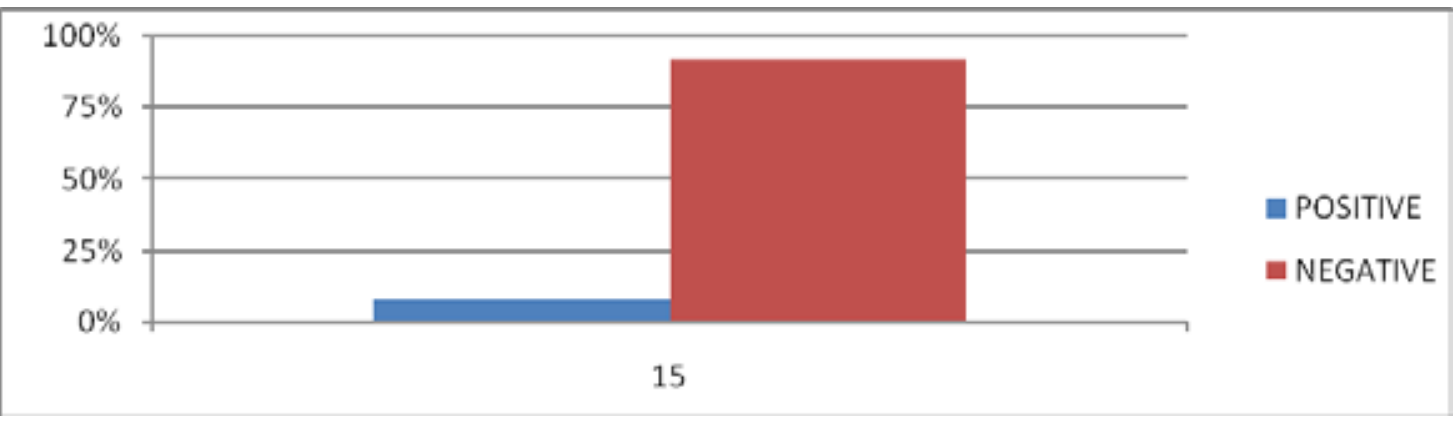

Figure 10. Question 15

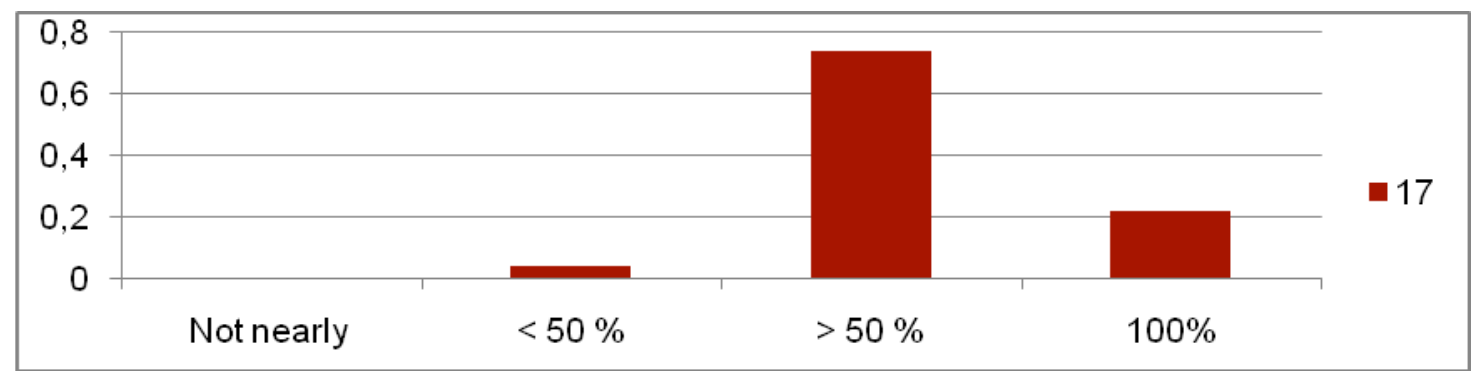

Figure 11. Question 17 athlete questionnaire

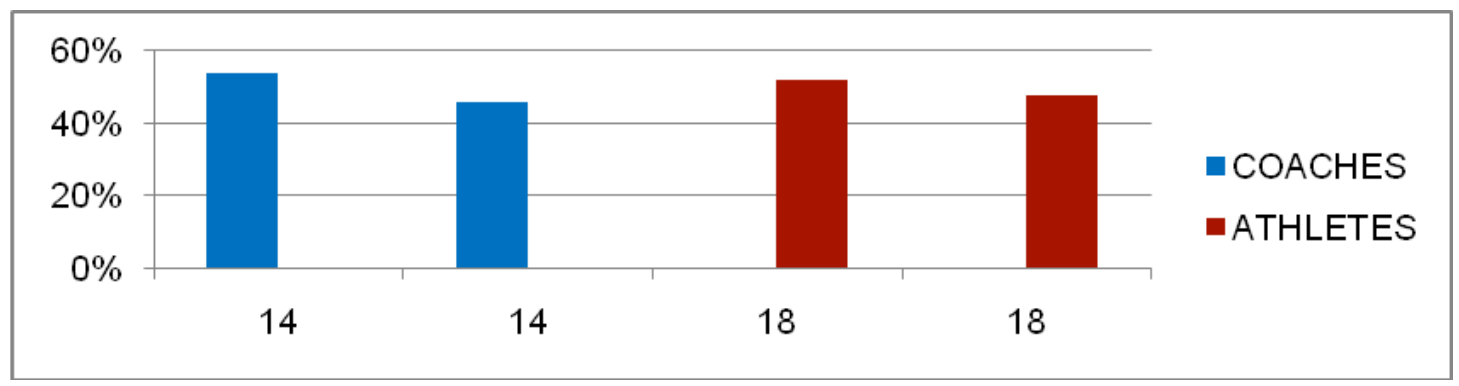

Figure 12. Question 14 (coach questionnaire) Question 18 (athlete questionnaire) 


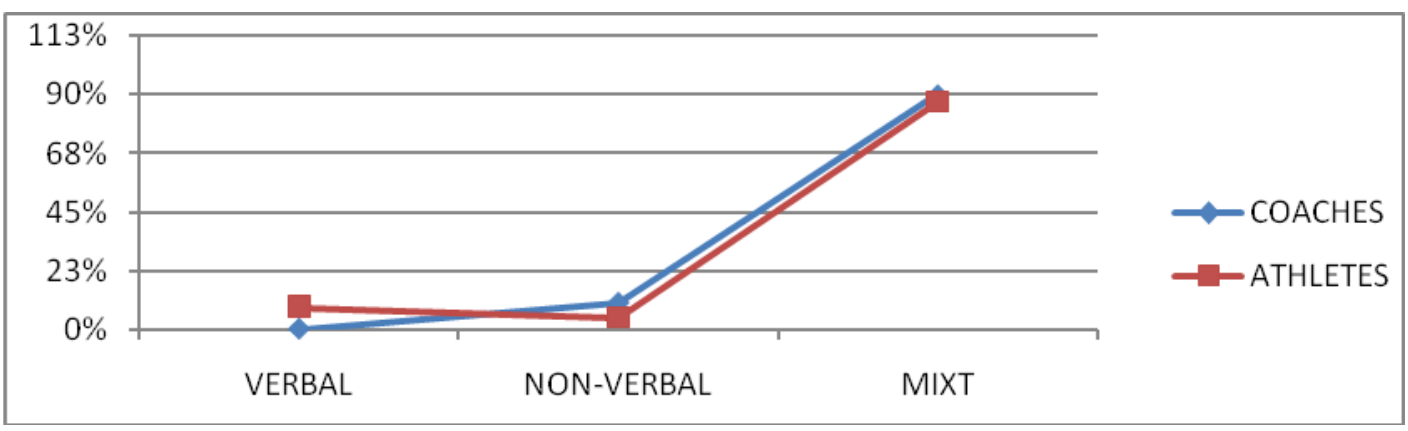

Figure 13. Questions 25, 28 (coaches) Questions 30, 35 (athletes)

figure, where the masters are represented by the blue color and the apprentices by the red color. The first column represents the positive answer while the second column the negative one.

To question 7, "When you have something to say or object, does the coach listen to you?" $92 \%$ of athletes responded affirmatively while only $8 \mathrm{~T} \%$ responded negatively. Out of the $8 \%$, the majority affirmed that they felt discouraged, demotivated or felt that they were losing trust or faith. To question 8 , question with an open answer, the athletes were supposed to talk about how they felt when the coach didn't listen to their opinion. A smaller amount of subjects, from collective sports, have said that in these kind of situations they felt as if they didn't matter in the team nor that their opinion was taken into account. Such views indicate that the master of the team is only the coach and that he/she does not collaborate with the players that he/ she is instructing. Another aspect could be that coach indeed works more or less with certain subjects.

The majority of coaches responded that they wish to have a stronger bond with the athletes and determine them to talk more. This comes in quite of a bit of contradiction, because at question 8 , if they feel satisfied of how the athletes communicate with them, $69 \%$ responded affirmatively and only 31\% responded negatively. The fact that the coaches want their athletes to talk more, to try to be more open, all of these indicate that they are involved and committed for the athlete's wellbeing, implicitly for their own good. A committed coach helps the athlete's evolution and wellbeing. Whereas the athletes have said they wished their guiders were calmer and more forbearing, which means an aggressive or authoritarian character is less agreeable.

"After a defeat, do you make reproaches right after the game or do you try and analyzefirst the situation andthen communicate with the athlete?" To this question, question 9, the majority declared they talkabout the result right after the end, as shown in the figure below.

This question has had an open answer where the instructors had to describe or explain why they talk or don't talk with their athletes' right after a defeat. The ones saying that they talk to the athletes after a defeat said that they analyze the match together because everything is so fresh in their minds, but the analysis is a positive one. Only after a period of time (undescribed here) do they make a more detailed and thorough analysis with possible reproaches. A lot of them consider that this communication method help athletes to cope easier with defeat. Coaches know that defeat is hard to swallow and they do not want to discourage even more the players, but on the contrary, they want to motivate them by making them aware of their mistakes. The numeric inferiority which said that it does not communicate with the athletes after a defeat, wishes the athletes to calm down first, giving the coach the possibility to individually analyze the recently obtained result, after which a more detailed analysis will take place but together. The coaches also said that this method differs from athlete to athlete. The players are different, they have different personalities and the coach-athlete communication differs from case to case. However, the coaches who do know their athletes, know exactly what method must be applied and when. This indicates o strong relationship between the coach and athlete. They know each other and their common objective is obtaining positive and multiple results by improving the instruction methods.

The questionnaire questions are similar, both to masters and to apprentices, to further notice the opinion of the two sided and to further compare them. To question 15 (athlete questionnaire) the subjects were asked to offer information regarding being ever intentionally hit by coaches. The majority answered with a negative response, nevertheless the same question was asked to coaches (question 12) and here the answer was unanimously negative. The athletes' response representation can be seen the following figure:

One can notice that the coach does not want to reveal this kind of information, even though the questionnaire is anonymous. The coaches' responses cannot be $100 \%$ correct, for the athletes' responses contradict their affirmations. These kind of delicate questions are meant to be asked on both sides to have opinions from different directions.

The athletes were asked to declare to what extent they respect the coach's indications before 
the competition and they had to choose for question 17 between four variants of response. $96 \%$ of subjects declared they respect over $50 \%$ of the indications given by the instructor and only $4 \%$ apply less than half of the coach's guidance. The athletes had to choose between the following variants: "nor nearly", "less than 50\%", more than 50\%" and "100\%". These can be shown the figure below:

This high percentage of athletes stating that they respect the coach's indications more than $50 \%$ during a competition illustrates the fact that the athletes do trust the coach's experience and abilities.

To the question "Does it happen for the coach to tell you something but from his gesture and mimic you might understand something else?" over a bit 50\% both coaches and athletes responded affirmatively. This was question 18 for the athletes and question 14 for the coaches. This shows that the verbal message contradicts the non-verbal message, instead of sustaining it. The percentages of the given answers can be seen in the following figure, where the first column either blue or red represents the affirmative answer and the second column either blue or red the negative answer.

When it comes to the way of communication, the athletes and coaches have had to choose between the verbal, the non-verbal and a combination of the two. The following figure illustrates the percentage in which they prefer the communication to take place, both during trainings and during competitions.

Both masters and apprentices consider the communication with the coach and the members of the team during a competition more efficient than communication only with the coach or only with the members of the team.

At the end of the questionnaire, the coaches were asked the following question: "Do you find it easy/ hard to read the athlete's feelings during a match?" $85 \%$ of them responded affirmatively and only $15 \%$ responded negatively. The subjects were asked to motivate their choice. They said they find it easy to read the athlete's feelings for they know quite well the athlete they are instructing. Due to body language, gestures and mimic they can tell what is happening inside the player without the latter verbally expressing it. But in order to know or correctly read these non-verbal messages, the people involved must know each other, and this mutual process must occur during time, during a longer period of time and under different situations. But even then the verbal messages can contradict the non-verbal ones and the receiver cannot always correctly decode them, as previously shown with question 14 and 18 from the two questionnaires.

Conclusions. One has noticed that the aggressive attitude or aggressive gestures of a certain coach demotivates players and the credibility slowly decreases. The athletes often reject these behaviors and react consequently.

One recommends the coaches be in a continuous development, to document themselves on different subjects. The majority already does. They wish to have a good rapport with their athletes; they want to make them talk more, being fully aware that only this way they can trust each other. Furthermore, only a strong team behind an athlete can lead to the top of the leader board.

Being a subject that is part of the individual's emotional sphere, in the beginning, the subjects were reticent in filling out the questionnaires, although one mentioned that the personal data would be necessary for statistical indication of the research. Only after communicating that the questionnaire is anonymous, only then did they start sharing what they were thinking.

After the questionnaires were filled in, with certain subjects we had more thorough discussions on the subject of the paper. After a period of time they said that indeed the way of communication has a certain effect on the master - apprentice relationship, thus giving much more attention to this aspect. They could notice positive results after a short time of applying new methods of communication and instruction.

\section{REFERENCES:}

1. Bloom, Schinke \& Salmela. 1997. P. 3, apud. Niko Härkönen \& Roman Klicznik. 2014. P. 9

2. 1999, in Nelson et al. 2014. P. 114, apud. Härkönen \& Klicznik. 2014. P. 3.

3. Hardy, Burke \& Crace. 2005. p. 192 ; Zyl van 2011. P. 5-6, apud. Niko Härkönen \& Roman Klicznik. 2014. P. 9.

4. Kassing\& Sanders. 2010, apud. Mazer et al. 2013. P. 204.

5. Madalina Catu. 2919. Elemente esentiale in comunicare an onverbala.

6. Shimazaki T., șiKikkawa M. A Study of Nonverbal Communication by Coaches: Relationships between Communication Ability and Coaching Evaluation, Paper : Coaching and Training, International Journal of Sport and Health Science, Vol. 13. 2012. P. 427-447. Japonia, online 21 mai 2015. P. 43-60.

7. URL: https://www.academia.edu/23829775/ Aggressive_Communication_in_the_Coach_Athlete_ Relationship (accessed: 28.04.2018).

8. URL: https://www.academia.edu/36840607/Tipuri de_chestionare (accessed: 02.06.2019).

9. URL: https://alindiaconu.blogspot.com/2011/09/ psihologie-sportiva-violenta-si.html (accessed:02.05.2019).

10. URL: http://www.conferintedefs.ase.ro/2013/ PDF/Sport \%20de\%20performanta/25\%20lacobini\%201.pdf (accessed: 01.05.2019).

11. URL: http://www.fefsoradea.ro/Fascicula_Educatie_Fizica_si_Sport/2012/10.FEFS_2012_Trifa.pdf (accessed: 04.05.2019). 